\title{
Impact of agricultural credit on economic growth in Nigeria
}

\author{
MOSINMILEOLUWA AFOLABI \\ Department of Banking and Finance, \\ Covenant University \\ Km 10, Idiroko, Ota. \\ NIGERIA \\ OCHEI AILEMEN IKPEFAN \\ Department of Banking and Finance, \\ Covenant University \\ Km 10, Idiroko, Ota. \\ NIGERIA \\ GODSWILL OSAGIE OSUMA \\ Department of Banking and Finance, \\ Covenant University \\ Km 10, Idiroko, Ota. \\ NIGERIA \\ GRACE EVBUOMWAN \\ Department of Banking and Finance, \\ St Augustine University, Epe, Lagos State. \\ NIGERIA
}

\begin{abstract}
This study's aim was to examine the influence of agricultural credit on Nigeria's economic growth for the period of 1981-2017. Data is sourced from Central Bank of Nigeria (CBN) statistical bulletin and world development indicator (WDI). The detailed objectives are to analyze the effect of the Agricultural credit guarantee scheme fund (ACGSF) and the deposit money bank credit to agric sector (DMBCA) on Nigeria's Economic Growth. Data was analyzed using the test for stationarity, Auto-Regressive Distributed Lag (ARDL). ARDL is adopted due to the mixed order of stationarity of the variables at levels and first difference. From the research results, it was established, in the long run, that DMBCA is significant and there exists a direct relationship, only in the short run, and the ACGSF is insignificant both the short and long run but has a direct relation in the short run and an inverse relationship in the long-run. Therefore, it is recommended, that the Federal Government should make coordinated attempts to ensure that farmers especially small-scale farmers have easy access to the financial aids and grants provided and the funds should be disbursed appropriately and adequately without any hitch.
\end{abstract}

Key-words: agricultural credit, agricultural sector, deposit money bank, economic growth, agricultural credit guarantee scheme fund, autoregressive distributed lag

Received: July 5, 2020. Revised: February 25, 2021. Accepted: March 2, 2021. Published: March 5, 2021. 


\section{Introduction}

Agriculture is the oldest and most significant occupation of man. It consists of; soil cultivation for planting crops \& rearing animals to supply food, wool, and other products for personal or general consumption. [1] concluded that, before oil was discovered and a decade after independence, Nigeria was designated as an agrarian economy based on its position as the basis for economic growth, as it became the primary industry contributing approximately 70 percent of the Gross Domestic Product (GDP), 90 percent of foreign exchange and Federal government revenue and provided employment to $70 \%$ of the labor force. Furthermore, she was the second $\left(2^{\text {nd }}\right)$ key cocoa producer in the world, the leading exporter and manufacturer of palm oil, groundnuts, cotton, hides, and rubber, according to [2] and the largest economic sector accounting for over $2 / 3$ of Nigeria's earnings from export during the colonial era. Nonetheless, throughout the war i.e., civil (1967-1970) and after the oil discovery in Nigeria, agrarian contributions decreased significantly arising from the failure to plan effectively for sustainable development. The oil boom in the 1970s caused distress in agrarian contribution to GDP (AGDP) and [3], noted that AGDP decreased from $60 \%$ in the early $1960 \mathrm{~s}$ to $48.8 \%$ in the 1970 s, to $22.2 \%$ in the 1980 s and $26.2 \%$ in 2000. The introduction of low cost imported goods quickly turned Nigeria, a major agrarian net exporter country, into the main importer of agrarian commodities. Nigeria's agrarian sector contribution to GDP is still below average at around 26.15 percent, which is still very low compared to its contribution to GDP in the 1960s as observed by [4].

Credit is a required tool for agrarian growth as it constitutes the ability to acquire all other inputs and is given to farmers in the form of loan to encourage agriculture, which is crucial for development to take place. According to [5], obtaining loan facility is a significant consideration in agriculture as well as other assets which are: Land, Labor, Equipment, and Raw materials.

In recognition of the agricultural industry's role in the Nigerian economy, the federal government of Nigeria (FGN) developed and enforced a number of financial programs through the apex bank i.e., Central Bank of Nigeria (CBN), all pointed at ensuring that funds are available to improve the real sectors, particularly the agricultural sector leading, among others, to development and economic growth. The previous schemes included are. :-

a. The establishment of the compulsory sectoral allocation to agriculture (1972): This is the FGN premeditated efforts in providing funds through DMBs to the agrarian sector, instructed to give a precise proportion of their total annual lending as loans to the agrarian sector at concessional rate of interest so as to increase agricultural yield.

b. Nigerian Agricultural, Cooperative, and Rural Development Bank - \{(NACRDB now: Bank of Agriculture-BOA, Ltd 1973)\}: The Nigerian Agricultural \& Cooperative Bank (NACB) Ltd was instituted by FGN in 1973 with a sole purpose of granting medium and longterm credit facilities to increase agricultural output and also address the challenges of low savings, insufficient investment, and lack of entrepreneurial skills, thus promoting rural and agricultural progress. In the month October 2000, NACB effectively joined with the nonextant Peoples Bank of Nigeria (PBN) and the risk capital of the Family Economic Advancement Programme (FEAP) to form the (NACRDB) Ltd which became BOA in 2011.

c. The Agricultural Credit Guarantee Scheme Fund - (ACGSF, 1977)\}: It was set up by the Government of the federation's military regime in 1977, began operations in 1978, with core objectives of insuring the risks of DMBs involved in agrarian lending so as to promote the continuation of extending loans to the agrarian sector. ACGSF guarantees agric loans (75\% of the amount not repaid) authorised and issued by DMBs to farmers, co-operatives, joint trading groups that are connected with the production of rubber, cocoa, oil palm tea, coffee.

d. The Rural Banking Setting Scheme\{(RBS,1977)\}: The purpose of this scheme was to gather and channel $50 \%$ of total deposits of DMBs situated in the local areas to mostly rural agricultural entrepreneurs, not just to boost economic progression only but also to raise banking cognizance amongst the rural 
inhabitants, in order to have one bank branch in every local government area.

\section{e. Agricultural Credit Support Scheme} \{(ACSS, 2006 till date)\}: Central Bank of Nigeria in collaboration with some other bank institutions created and developed this scheme, making huge donations for its operations in order to finance huge agric projects; crop production, mechanised farming, animal rearing, plantation management. It was created to provide a leverage for farmers in making use of the vast potentials of agriculture, generating cash crops and varieties for export, strengthening our foreign earnings, and decreasing inflation [6].

f. Nigeria Incentive-Based Risk Management System for Agricultural Lending- \{(NIRSAL, 2011)\}: It is an institution which serves as a risksharing barrier among DMBs, farmers and investors in respect to agriculture lending. It was formed to reduce DMBs' identified risks in the agrarian sector through the risk apportioning method business project for DMBs to lend to agrarian sector as against other sectors and also lower the cost of lending for the DMBs

g. Anchors Borrowers Programme- \{(ABP, 2015)\}: This scheme was established to form a relationship between anchor companies that deals with the processing and small- scale farmers of the leading agricultural products needed. ABP's program focus is to supply farm resources (either in kind and cash) to smallscale farmers so as to enhance production of the agric goods, provide resource supplies to agroprocessors and tackle Nigeria's negative balance of payments on food.

[7] stressed that sustained agrarian growth is an important aspect in eradicating hunger and poverty as it contributes to reasonable price stability and food availability, ensures highcapacity nation industrial growth via even processing of raw materials and output, the release of labor, and subsequently through full employment. The Nigerian agrarian sector has continued to raise comparatively less than the government's proportionate amount of funds. [8] observed that though there has been implementation of numerous reforms in the Nigerian banking sector, the agrarian sector is still confronted with the issue of accessing financial resources, especially from DMBs which holds about 90 percent of the overall assets of the financial sector and also high rate of interest, thus preventing many firms from bank -borrowing. Certain funding challenges include bank loan concentration on oil \& gas, telecommunication \& general trade industries to the detriment of principal real sectors such as agriculture \& manufacturing. This poses the question of why the banking reforms, credit schemes, and financial aids allegedly provided to drive and develop the agrarian sector has not had a significant influence on Nigeria's economic growth?

[9] stated that increased agrarian productivity in an agrarian economy is certainly, a vital prerequisite for rapid economic growth and development.

\subsubsection{Research questions}

Some research questions to be considered in the study are:

1. To what extent has sectoral deposit money bank credit to agriculture affected Nigeria's economic growth?

2. To what extent has agricultural credit guarantee scheme fund affected Nigeria's economic growth?

\subsubsection{Research objectives}

The main objective of the study is to examine the influence of agricultural financing on economic development in Nigeria.

The study's detailed objectives are to examine:

1. The effect of deposit money bank loans to agriculture on economic Growth in Nigeria

2. The influence of agricultural credit guarantee scheme fund on economic Growth in Nigeria.

\subsubsection{Research hypotheses Hypothesis One}

$\mathbf{H}_{\mathbf{0}}$ : Sectoral deposit money bank loans to agriculture have no significant effect on Nigeria's economic growth.

\section{Hypothesis Two}

$\mathbf{H}_{0}$ : agricultural credit guarantee scheme fund has no significant effect on Nigeria's Economic Growth. 


\section{Literature review Conceptual framework}

[10] described agrarian credit as use of credit through every stage so as to enlarge and enhance agricultural production and efficiency.

[11] affirmed that economic growth is the increase in the aggregate output of an economy, excluding reference to inflation, deflation, or the entire population.

[12] reiterated that without credit, farmers will not be able to take advantage of the latest machineries, valuable seeds, fertilizer, livestock and workforce all of which permits the farmers to structure and run their farm businesses on a more lucrative basis.

[13] defined agrarian credit as one of several payment instruments used to fund agricultural transactions. This type of funding is tailored to suit the farmer's particular financial need, which is influenced by the planting, harvesting and marketing periods. Example are loans, accounts, bills of exchange and banker's acceptance

[14] inferred that economic growth is an increase in the creation of economic goods and services, compared from time to time.

\subsection{Theoretical review}

\section{Commercial Loan Theory of Liquidity/Real bill Doctrine}

This Study anchors on the Commercial Loan Theory of Liquidity. [15] propounded this theory in 1776. He used this principle in regards to bank's liquidity stating that the best quick cash payments DMBs can make are advanced short-term loans used to fund saleable products on the way from producer to customer. It also states that short-term, self-liquidating loans should be granted by deposit money banks to lucrative / profitable corporate organisations. A self-liquidating loan is used to fund the production and supply of goods in consecutive stages, the liquidation of loans is anticipated when such goods are sold according to [16].

The Real Bills Theory can be easily illustrated as a transaction between a bank and a business that creates money in the economy. A maize seed supplier supplies a farmer with One Hundred Thousand Naira $(\$ 100,000)$ worth of maize seeds and an invoice with payment due in 90 days is written, after planting, harvesting, processing and sales over the 90-day period, the farmer agrees to repay the loan. The supplier has in fact developed commercial paper with a value of one hundred thousand Naira (N100,000).

The theory postulates that when DMBs limit their advances to short- term liquidating productive loans, the apex bank should also limit their advances to banks on the security of such short- term loans. This notion would ensure that there is an appropriate amount of liquidity for the DMBs and adequate money supply for the economy. DMBs are therefore expected to fund the agrarian sector through the granting of credit to farmers to finance their working capital needs.

\subsection{Empirical review}

The effective synergies between agrarian funding and economic Growth of Tanzania was analysed by [17]. The recently developed asymmetric Auto-Regressive Distributed Lag (ARDL) cointegration methodology was applied in the research work. It was revealed that favourable disturbances of agrarian funding have a significant influence on economic growth as equated to unfavourable disturbances, while any adverse economic situation would negatively affect agrarian funding. This research concluded and recommended that the present lopsided nexus between agrarian funding \& economic growth should be taken into consideration \& the government should boost its funding to the agrarian sector.

The effect of the ACGSF on the agrarian sector development in Nigeria was examined by [18]. The timeframe for the research was 1981-2016 and the specific goals were to determine whether ACGSF had a significant relationship with Nigeria's crop industry production, livestock industry, and fisheries industry. The multiple OLS technique was used in this study to analyze the variables and a direct \& significant relationship between ACGSF and the agric sector was found. 
The nexus between agrarian funding and Nigeria's economic growth was examined by [19]. This research work made use of the ARDL estimation method to explore the nexus between agricultural financing \& Nigeria's economic growth. Research results specified that there exists a short \& long- run link between agrarian funding and Nigeria's economic growth. The study concluded that the explanatory variables agric loans, exchange rates (real), rate of interest (real), domestic private investment and inflation affects Nigeria's GDP. The study proposed that concerned measures be taken by policymakers in expanding efficiency level of Nigeria's agrarian sector by providing it with sufficient credit to boost Nigerian economic growth.

[20] evaluated the influence of DMBs' loans on Nigeria's agricultural output. For the paper, the research design that was adopted was ex-post facto. The scope of the work was from 19702014. The paper applied the OLS method to estimate the variables and a direct and significant relationship was established among ACGSF, DMBs' funds to the agrarian sector, expenditure of the government on agriculture and Nigeria's agrarian output respectively. The study however opined that there was an inverse $\&$ insignificant link between the rate of interest $\&$ agrarian output.

[21] explored the influence of DMBs' credit on the Growth of Nigeria's agrarian sector. Data was analysed via the ordinary least square (OLS) multiple regression approach. It was revealed that both ACGSF and DMB lending rate had an insignificant relation with the AGDP. The research work suggested that there should be an increment in loans and advances(L\&A) being given to the agrarian sector but should be at a low rate of lending and also the requirements to be met by farmers prior to assessing the ACGSF be reviewed.

[22] explored the agrarian credit potential, performance and the link with India's agrarian growth. The study applied Johansen Cointegration test to explore the long- term link between AGDP \& agrarian credit. Results from the analysis noted that over the period, AGDP is extremely receptive to an increase in agrarian credit. A unidirectional causality exists between agrarian credit and AGDP. The research work commended that for financial and social inclusion, the government should take effective steps in disbursing credit to the agrarian sector as it leads to increased production. Moreso, agriculture has the power to promote general growth in all sectors of the economy.

[23] carried out a research in which he assessed the problems and possibilities of supporting Nigeria's agriculture cooperatives by evaluating the data using the statistics of the Chi-Square and the Coefficient of Spearman. The findings of the study stated that no paramount priority was given to extending financial institutions loans to agrarian cooperatives and that the problem for agrarian cooperative funding in Nigeria include lack of loan facility, default on loans, lack of fundamental infrastructure, lack of securities and technical skills.

\section{Methodology}

The study used E-views 9 for the data analysis, a test of unit root was conducted to know the stationarity of the variables. The test results revealed that variables (SDMBCA, ACGSF, INFL, OEXR) were stationary at first $\left(1^{\text {st }}\right)$ difference while GDP and RINT were stationary at levels. Hence, ARDL technique was applied to check for short \& long run relationship amongst the variables due to mixed stationarity levels of order I (0) and I(1).[24] noted that the main advantage of ARDL is that OLS method provides accurate estimates of parameters over other estimation methods and it is a reliable parameter estimate if some variables are $1(0) \&$ 1(1) which basically means that there is a longterm link amongst the variables. The following shows the model specification:

\subsection{Model specification}

$G D P=\beta_{0}+\beta_{1} D M B C A+\beta_{2} A C G S F+\beta_{3} R I N T$ $+\beta_{4} I N F L \varepsilon+\beta_{5} O E X R+\varepsilon$

Apriori expectation of the study is $\beta_{1}-\beta_{3}>0$

Where:

$R G D P=$ Gross Domestic Product

DMBCA = Deposit Money Bank Credit to Agriculture

ACGSF = Agricultural Credit Guarantee Scheme Fund 
RINTR $=$ Interest Rate $($ Real $)$

INFL- Inflation Rate

OEXR-Official Rate of Exchange

$\varepsilon$-Error/disturbance term

$\beta 1-\beta 3=$ Coefficient of the independent variables

$\beta_{0}$ is the regression intercept, $\beta_{1}-\beta_{3}$ are the regression coefficient while the error term is $\varepsilon$.

Implicit form: GDP = f (DMBCA, ACGSF, RINT, INFL, OEXR)

Re-writing (1) in its explicit and econometric form, we have:

$\mathrm{GDP}=\beta_{0}+\beta_{1} D M B C A+\beta_{2} A C G S F+$

$\beta_{3} R I N T+\beta_{4} I N F L+\beta_{5} O E X R+\mu$
ARDL Model: $\quad \Delta G D P_{t}=\beta_{0}+$
$\sum_{i=0}^{n} \Delta \beta_{1} D M B C A_{t_{-1}}+\sum_{i=0}^{n} \Delta \beta_{2} A C G S F_{t-1}+$
$\sum_{i=0}^{n} \Delta \beta_{3} R_{N} I T_{t-1} \quad+\sum_{i=0}^{n} \Delta \beta_{4} I N F L_{t-1}+$
$\sum_{i=0}^{n} \Delta \beta_{5}$ OEXR $_{t-1}+\sum_{i=0}^{n} \beta_{6} S D M B C A_{t-1}+$
$\sum_{i=0}^{n} \beta_{7}$ ACGSF $_{t-1}+\sum_{i=0}^{n} \beta_{8} R I N T_{t-1}+$
$\sum_{i=0}^{n} \beta_{9} I N F L_{t-1}+\quad \sum_{i=0}^{n} \beta_{10} O E X R_{t-1}+\varepsilon_{t}$

Where $\Delta=$ the first difference operator

$\mathrm{t}-1=$ the previous year

$\mathrm{n}=$ summation of the period

The explanatory variables are presented in their differential forms, which shows the changes in the explanatory variables over time both in the previous and present time.

Table 1 Justification of the dependent and independent variables

\begin{tabular}{|c|c|c|c|}
\hline Variable Name & Identifier & $\begin{array}{l}\text { Source of } \\
\text { data }\end{array}$ & Definition and Measurement \\
\hline $\begin{array}{l}\text { Gross Domestic } \\
\text { Product }\end{array}$ & GDP & WDI & $\begin{array}{l}\text { It is known as the total monetary worth of all } \\
\text { completed goods \& services manufactured within a } \\
\text { country's borders at a particular period. }\end{array}$ \\
\hline $\begin{array}{lr}\text { Deposit } & \text { Money } \\
\text { Credit } & \text { to } \\
\text { Agriculture } & \\
\text { Sector } & \end{array}$ & DMBCA & $\begin{array}{l}\text { CBN } \\
\text { Statistical } \\
\text { Bulletin }\end{array}$ & $\begin{array}{l}\text { It refers to a certain percentage of funds granted by } \\
\text { DMBs to the agriculture sector at a rate of low } \\
\text { interest. This is was made mandatory via the CBN. }\end{array}$ \\
\hline $\begin{array}{l}\text { Agriculture Credit } \\
\text { Guarantee } \\
\text { Scheme Fund }\end{array}$ & ACGSF & $\begin{array}{l}\text { CBN } \\
\text { Statistical } \\
\text { Bulletin }\end{array}$ & $\begin{array}{l}\text { It is a scheme managed by }(\mathrm{CBN}) \text {. It offers } \\
\text { guarantee to DMBs that lends to the agrarian sector } \\
\text { of the economy. This encourages the banks to grant } \\
\text { more loans to the farmers. }\end{array}$ \\
\hline $\begin{array}{l}\text { Real Rate of } \\
\text { Interest }\end{array}$ & RINT & WDI & $\begin{array}{l}\text { It can be defined as an interest rate that has been } \\
\text { altered to eliminate the influence of inflation to } \\
\text { indicate the real cost of funds to the borrower and } \\
\text { the real return to the lender or an investor. }\end{array}$ \\
\hline Inflation Rate & INFL & WDI & $\begin{array}{l}\text { It can be defined as the percentage rise in overall } \\
\text { level of cost of goods \& services over a period. }\end{array}$ \\
\hline $\begin{array}{l}\text { Official Rate of } \\
\text { Exchange }\end{array}$ & OEXR & WDI & $\begin{array}{l}\text { It refers to the rate at which the currency of one } \\
\text { country can be traded for the currency of another } \\
\text { country. This is the determined by the national } \\
\text { authorities of the country }\end{array}$ \\
\hline
\end{tabular}

Source: Authors' compilation (2019)

\section{Data Results, Interpretations and Discussions}

This involves analysis, interpretation of data and presentation of findings from the research methodology. Data analysis was done using ARDL and granger causality technique via EViews statistical software (version 9.0) for period between 1981 and 2017. 
Table 2 Unit root test

\begin{tabular}{|l|l|l|l|}
\hline Variable & T-Stat & P-Value & Order of Integration \\
\hline GDP & -4.045483 & 0.0034 & I $(0)$ \\
\hline DMBCA & -6.628472 & 0.0000 & I (1) \\
\hline ACGSF & -7.012424 & 0.0000 & I (1) \\
\hline RINT & -5.961293 & 0.0000 & I $(0)$ \\
\hline INFL & -5.514745 & 0.0001 & I (1) \\
\hline OEXR & -3.297372 & 0.0227 & I (1) \\
\hline
\end{tabular}

Source: E-Views Output,2019

Unit root test conducted shows that variables (DMBCA, ACGSF, INFL, OEXR) are integrated at first $\left(1^{\text {st }}\right)$ difference while GDP and RINT are stationary at levels. Hence, ARDL technique is adopted to check for short and long run relationship among variables due to mixed stationarity of I (0) and I (1).

Table 3 ARDL short run result

\begin{tabular}{|c|c|c|c|c|}
\hline \multicolumn{5}{|c|}{ Dependent Variable: GDP } \\
\hline \multicolumn{5}{|c|}{\begin{tabular}{|l|l} 
Method: ARDL & \\
\end{tabular}} \\
\hline \multicolumn{5}{|c|}{ Maximum dependent lags: 2 (Automatic selection) } \\
\hline \multicolumn{5}{|c|}{ Model selection method: Akaike info criterion (AIC) } \\
\hline \multicolumn{5}{|c|}{ Dynamic regressors (2 lags, automatic): DMBCA ACGSF RINT INFL OEXR } \\
\hline \multicolumn{5}{|c|}{ Selected Model: ARDL $(1,0,0,0,1,1)$} \\
\hline Variable & Coefficient & Std. Error & t-Statistic & Prob. $*$ \\
\hline GDP (-1) & -0.065113 & 0.180796 & -0.360148 & 0.7215 \\
\hline DMBCA & -0.033308 & 0.016761 & -1.987220 & 0.0571 \\
\hline ACGSF & $7.31 \mathrm{E}-08$ & 5.94E-07 & 0.123179 & 0.9029 \\
\hline RINT & 0.185293 & 0.073391 & 2.524730 & 0.0178 \\
\hline INFL & 0.038729 & 0.081156 & 0.477219 & 0.6370 \\
\hline INFL (-1) & 0.107737 & 0.077055 & 1.398187 & 0.1734 \\
\hline OEXR & -0.050907 & 0.072295 & -0.704151 & 0.4874 \\
\hline OEXR (-1) & 0.148133 & 0.078715 & 1.881885 & 0.0707 \\
\hline $\mathrm{C}$ & -2.303767 & 2.565928 & -0.897830 & 0.3772 \\
\hline R-squared & 0.440930 & \multicolumn{2}{|c|}{ Mean dependent var } & 3.911535 \\
\hline Adj R- squared & 0.275279 & \multicolumn{2}{|c|}{ SD dependent var } & 7.076957 \\
\hline $\begin{array}{ll}\text { SE } & \text { of } \\
\text { regression }\end{array}$ & 6.024652 & \multicolumn{2}{|c|}{ Akaike info criterion } & 6.641915 \\
\hline Sum squared & 980.0038 & \multicolumn{2}{|c|}{ Schwarz criterion } & 7.037794 \\
\hline Log likelihood & -110.5545 & \multicolumn{2}{|c|}{ Hannan-Quinn criter. } & 6.780087 \\
\hline F-statistic & 2.661806 & \multicolumn{2}{|c|}{ Durbin-Watson stat } & 2.104135 \\
\hline $\begin{array}{l}\text { Prob(F- } \\
\text { statistic) }\end{array}$ & 0.027023 & & & \\
\hline
\end{tabular}

\section{Source: E-Views Output,2019}

From Table 3, the first period lag of GDP is statistically insignificant at 5\% level. Also, a percent increase in GDP for one year back will lead to about 6.5 percent decrease in current GDP.

DMBCA: DMBCA is statistically not significant at $5 \%$ level as test-stat is lower than 2 and prob-value is greater than 0.05 . A percent increase in the sectoral deposit money bank loans to agriculture will cause about 3.3 percent reduction in current GDP. This does not conform to theory the reason being that the SDMBCA is not performing as highly as it should be, thereby having an inverse influence on Nigeria's economic growth. 
ACGSF: At 5\% level, ACGSF is statistically insignificant as t-stat is below 2 and p-value is above 0.05. A unit rise in ACGSF would lead to an increase in current GDP of around 7.31 percent units. This positive relationship is in line with apriori expectations as higher loan funding for the agrarian sector will directly influence Nigeria's economic growth.

RINT: RINT is positively significant at $5 \%$ level as test-stat is higher than 2 and p-value is lower than 0.05 . One (1) percentage increase in real interest rate will yield about 18.5 percent increase in current GDP. This positive relationship does not conform to theory, because higher rate of interest increases the cost of borrowing and discourages investment for productive purposes, which in turn hampers economic growth. However, real interest rate in itself might not really matter for growth performance, if lending interest rate results in higher productive investment.

INFL: INFL is insignificant at 5\% level as teststat is lesser than 2 and p-value is higher than 0.05 . A percent rise in rate of inflation would yield about 3.9 percent increase in current GDP. This positive relationship does not conform to apriori expectation as higher inflation, especially at the extreme levels is a detriment to economic growth through higher cost of commodities and lower purchasing power. Nonetheless, in reality, low levels of inflation are beneficial for economic growth as it boosts employment and affords consumers the purchasing power to buy goods and services, which boost an economy's growth.

OEXR: OEXR is insignificant at 5\% level as test-stat is lesser than 2 and p-value exceeds 0.05 . A percentage rise in exchange rate will cause about 5 percent decrease in current GDP. This negative relationship does not conform to theory as higher exchange rate is supposed to cause currency depreciation, which would boost exports for a producing nation, thereby increasing production and economic growth. However, this is not the case for Nigeria as increased exchange rates does not increase exports despite naira depreciation, because Nigeria is more of a consuming nation, thereby negatively affecting economic growth. Interestingly, exchange rate for one year ago positively impacts GDP by about $14.8 \%$. DWstat is about 2.10 which shows that there is no presence of autocorrelation. $\mathbf{R}^{2}$ : All explanatory variables combined explain about $44 \%$ of the changes in GDP and after being adjusted for degree of freedom, Adjusted $\mathbf{R}^{2}$ depicts that all the explanatory variables explain about $28 \%$ of alterations in GDP. This could be because agricultural financing is just one of many aspects of sectoral determinants of economic growth. Hence, this model is a very good fit.

F-stat and Prob (F-stat): All independent variables are jointly significant at about 2.66 and about $1 \%$ level respectively in explaining changes in GDP

Table 4 Result of bounds test

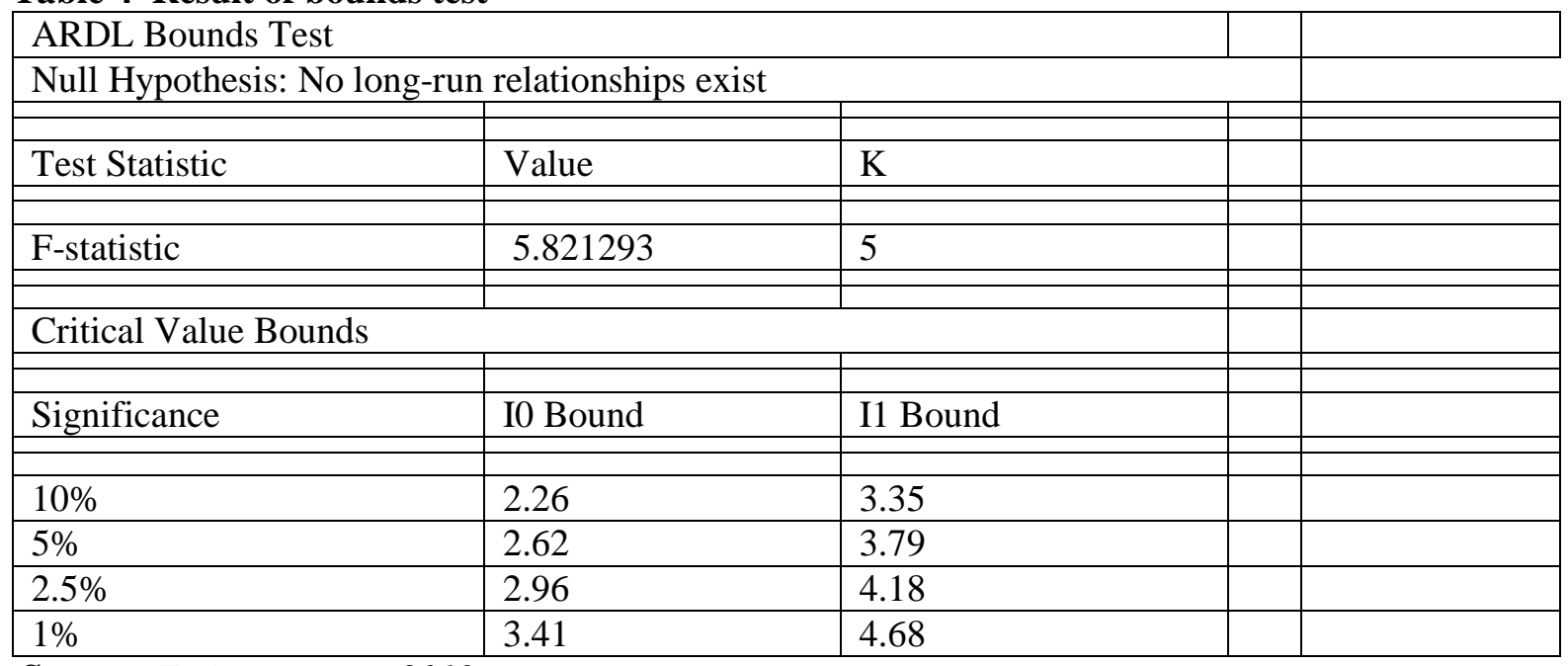

Source: E-views output, 2019 
F-stat value (5.82) exceeds all upper boundaries at 1\%, 5\% and 10\% significance levels, which conforms with decision criteria, so long- run relationship exists.

Table 5 Long run co-integration result

\begin{tabular}{|l|l|l|l|l|}
\hline Long Run Coefficients & & & \\
\hline Variable & Coefficient & Std. Error & t-Statistic & Prob. \\
\hline \hline DMBCA & -0.031272 & 0.013633 & -2.293800 & 0.0298 \\
\hline ACGSF & 0.000000 & 0.000001 & 0.124464 & 0.9019 \\
\hline RINT & 0.173965 & 0.069250 & 2.512129 & 0.0183 \\
\hline INFL & 0.137512 & 0.073847 & 1.862119 & 0.0735 \\
\hline OEXR & 0.091282 & 0.027405 & 3.330814 & 0.0025 \\
\hline CONSTANT & -2.162931 & 2.385909 & -0.906544 & 0.3727 \\
\hline CointEq(-1) & -1.065113 & 0.180796 & -5.891242 & 0.0000 \\
\hline $\begin{array}{l}\text { Source: E-Views Output (2019) } \\
\text { Cointeq = GDP - (-0.0313*DMBCA + 0.0000*ACGSF +0.1740*RINT } 0.1375\end{array}$ \\
\begin{tabular}{l}
$0.0913 *$ OEXR -2.1629). \\
\hline
\end{tabular}
\end{tabular}

Source: E-views output, 2019

\section{Long run result:}

$\mathrm{GDP}=2.1629+0.0313 \mathrm{DMBCA}-$ 0.0000ACGSF - 0.1740RINT - 0.1375INFL 0.0913OEXR

Table 5 presents the ARDL long term relationship of the above model. the constant term implies that in the absence of all explanatory variables (DMBCA, ACGSF, RINT, INFL and OEXR), economic growth will be positive at about 2.16 percent.

DMBCA: is positively significant at 5\% level with test-stat of more than 2 and p-value of less than 0.05. A percent rise in deposit money bank's loans to agriculture will cause about 3.1 percent rise in current GDP in the long term. This direct relationship conforms with apriori expectation as it indicates that DMBCA will be performing much better in the future to positively impact Nigeria's Growth.

ACGSF: is insignificant at 5\% level as test-stat is lower than 2 and p-value is greater than 0.05 . A unit rise in Agricultural Credit Guarantee Scheme Fund will yield no change in current GDP on a long-term basis. This negative relationship implies that credit scheme effects will wear off in the long run as other factors will come into play in influencing a nation's growth.
RINT: RINT is positively significant at 5\% level as test-stat exceeds 2 and p-value is lower than 0.05. A percentage rise in real interest rate will yield about 17.4 percent decrease in current GDP. This negative relationship conforms with theory because increased interest rates will raise the cost of borrowing, which will then discourage lending for productive investment ventures, thereby negatively impacting GDP in the long run.

INFL: INFL is insignificant at 5\% level as teststat is lesser than 2 and p-value exceeds 0.05 . One percent rise in inflation rate will bring about $13.8 \%$ decrease in current GDP. This negative relationship conforms to apriori expectation as high inflation reduces individuals' purchasing power, which makes it more expensive to buy products and vital utilities, thus adversely affecting growth levels of the Nigerian economy in the future.

OEXR: EXR is positively significant at 5\% level as test-stat exceeds 2 and p-value is lesser than 0.05 . A $\%$ rise in official rate of exchange will cause about 9.1 percent decrease in current GDP. This negative relationship does not align with theory as higher exchange rate causes depreciation of the naira, which is theoretically meant to boosts export levels However, for a 
country like Nigeria that is more of a consuming than a producing nation, this currency depreciation will not necessarily boost exports, which then negatively affects economic growth in the future

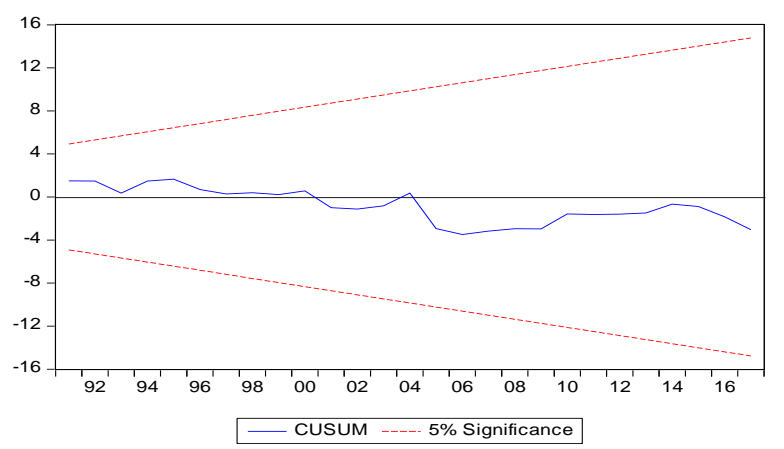

Fig 1 Stability Cumulative Sum (CUSUM) Test Source: E-views output, 2019

Figure 1 presents graph using cumulative sum (CUSUM) test. The line must lie between upper and lower boundaries. The graph satisfies this condition; therefore, it is significantly stable at $5 \%$ level.

\section{Test of Hypotheses}

The hypotheses are stated in their null form Hypothesis One $\mathrm{H}_{0}$

Deposit money bank credit to agriculture (DMBCA) has no significant influence on the economic Growth of Nigeria. From the results obtained in table 5, DMBCA is positively significant at $5 \%$ level with t-stat higher than 2 and $\mathrm{p}$-value of less than 0.05 . Hence, the alternative hypothesis is accepted while the null is rejected.

The alternative hypothesis to be accepted states that DMBCA is positively significant at $5 \%$ level with t-stat higher than 2 and p-value of less than 0.05 which means a percent rise in the deposit money bank's loans to agriculture will cause about 3.1 percent rise in current GDP in the long term.

\section{Hypothesis Two $\mathrm{H}_{0}$ :}

From the results obtained in table 5, Agricultural credit guarantee scheme fund (ACGSF) has no significant influence on the economic Growth of Nigeria. The findings revealed that, ACGSF is statistically insignificant at 5\% level as t-stat is lower than 2 and p-value is greater than 0.05. A unit increase in Agricultural Credit Guarantee Scheme Fund will bring about a no change in
From the table 5 (CointEq), Error Correction Model is negative illustrating convergence of errors. Hence, about 106 percent of errors generated in this period will be adjusted in the next period. current GDP on a long-term basis. Therefore, the null hypothesis is accepted while the alternative is rejected.

The null hypothesis reveals that ACGSF is statistically insignificant at 5\% level as t-stat is lower than 2 and p-value is greater than 0.05 which means a unit rise in Agricultural Credit Guarantee Scheme Fund will yield no change in current GDP on a long-term basis.

\section{Summary of Findings, Conclusion and Recommendations Summary of Findings}

The study seeks to examine the effect of agricultural credit for the period 1981-2017 on Nigeria's economic growth. Time series data was generated from the CBN Statistical Bulletin and WDI. The detailed objectives are to analyzed the effect of the agricultural loan guarantee system and the sector deposit money bank credit on Nigeria's economic growth. These were analysed using the ARDL and granger causality technique. ARDL was employed because of the mixed order of stationarity at rates and first difference.

DMBCA is statistically significant at a level of 5 percent as t-stat is higher than 2 and with a pvalue of 0.029 which is less than 0.05 in the long-run $\quad(p$-value $=0.029<0.05)$ but is not statistically significant in the short-run as the test-stat is lower than 2 and has a prob-value of 0.057 ( $\mathrm{p}$-value $=0.057>0.05)$ which is greater than 0.05, and it has a long-run positive 
relationship but a short-run negative relationship. This result is in tandem with [20] as they explored the influence of DMBs' credit on the Growth of Nigeria's agrarian sector ACGSF is statistically insignificant at 5\% level as test-stat is less than 2 and has a probabilityvalue of $0.9029(\mathrm{p}$-value $=0.9029<0.05)$ which is greater than 0.05 in both the short run and long run $\{(\mathrm{a}$ p-value of 0.9019 i.e $\mathrm{p}$-value $=0.9019$ $<0.05)\}$ but there is a direct relationship in the short run and an inverse relationship in the longrun. This result is not in tandem with [19] as they examined the nexus between agrarian funding and Nigeria's economic growth.

The Control Variables which are RINT, INFL and OXR are explained as follows: RINT is statistically significant as t- stat exceeds 2 and $\mathrm{p}$ value is 0.017 which is less than $0.05(\mathrm{p}$ value $=0.017<0.05)$ both in the short run and long- run $\{(\mathrm{t}$-stat is less than 2 and p-value is 0.018 which is less than 0.05 i.e pvalue $=0.018<0.05)\}$ but there exists a direct relationship in the short- run and an inverse relationship in the long -run. INFL is statistically insignificant as t- stat is lower than 2 and p-value is 0.63 which is greater than 0.05 (p-value $=0.63>0.05)$ in both the short-run and long-run $\{(\mathrm{t}$-stat is less than 2 and $\mathrm{p}$-value is 0.07 which is greater than 0.05 i.e p-value $=0.018$ $>0.05$ ) $\}$ but there exists a direct relationship in the short run and an inverse relationship in the long-run. OEXR is statistically not significant in the long run as $\mathrm{t}$ - stat is lower than 2 and $\mathrm{p}$-value is 0.37 which is greater than 0.05 ( $\mathrm{p}$-value $=0.37$ $>0.05$ ) whereas it is statistically significant in the short-run as t- stat is greater than 2 and pvalue is 0.00 which is less than 0.05 (pvalue $=0.00<0.05$ ), it has an indirect relation in both the short-run and long-run.

\section{Conclusion}

Credit is essential for the revival and development of Nigeria's agrarian sector according to [7], however, also pertinent are other development factors from which finance cannot be isolated if it is to be efficient and effective. To allow the agrarian sector get access to complete benefit of the multiple incentives and face challenges head on, credit to the agricultural sector has to be adequately funded, disbursed and monitored by the CBN to avoid mismanagement of funds as this will enable the funds to be easily accessible to the farmers. [25] further stated that improving the agrarian sector is a necessary condition for enhancing food security and it is mandatory that this be carried out in the framework of suitable monetary and fiscal policies to ensure more macroeconomic stability. Presently the government in collaboration with the CBN are focused on developing the value chain of the agrarian sector. Easy access to credit is also a tool for development as this will enable farmers purchase the necessary farm inputs which will lead to increase in output, especially with the closure of the border in 2019 (a ban was placed on rice and livestock importation) which has prompted any people to go into rice production to enhance supply. This will discourage import, encourage export and positively impact Nigeria's economic growth in the long run.

\section{Recommendations}

The study recommendations are as follows:

(a.) The Federal Government through the CBN should establish strict policies and rules to ensure that DMBs grant extra credit to the agrarian sector which should be at low rate of interest as this will lead to increase borrowing of funds for the purpose of agricultural production.

(b.) The Federal Government should actively increase its rate of investment in agriculture by increasing its financial aids and grant to agricultural firms and small-scale farmers and should also ensure that the farmers have easy access to the funds (i.e the funds should be disbursed appropriately and adequately) without any hitch.

(c.) The Nigerian government should strive to encourage the growth and development of the real sector particularly the agrarian sector as this will contribute to increased productivity and exports and a decrease in imports. This will definitely make Nigeria a producer nation and not a consumer nation alone.

\section{Acknowledgement}

The authors appreciate Covenant University Centre of Research and Innovation(CUCRID) for sponsoring the publication of the article. 
References:

[1] Ogen, .O. (2003). Patterns of Economic Growth and Development in Nigeria since 1960 in SO. Arifalo and Gboyega Ajayi (eds.) Essays in Nigerian Contemporary History. Lagos: First Academic Publishers.

[2] ] Alkali, R. (1997). The World Bank and Nigeria: Cornucopia or Pandora Box? Kaduna: Baraka Press.

[3] CBN. (2009). Annual Report and Statement of Accounts, For the Year ended 31st December, 2009, Abuja.

[4] National Bureau of Statistics (2018). Nigeria' Agriculture Contribution to GDP for the Year 2018, Retrieved from www.nbs.gov.sc. Accessed $14^{\text {th }}$ November, 2019.

[5] Adeoti, A.I. and Raji, M.A.Y. (2010). Determinants of Agricultural Credit Rationing by Commercial Banks in South-Western, Nigeria. International Research Journal of finance and Economics, Vol 37, pp 1450-2887

[6] Osabohien, R., Osabuohien, E., Obiekwe,.E. and Urhie, E.,.(Eds).(2018). Food security, institutional

framework, and technology: Examining the nexus in Nigeria using ARDL approach, Current Nutrition and Food Science, Vol 14, No 2, pp. 154-163.

[7] Famogbiele, A. (2013). The Challenges of Agricultural Finance in Nigeria: Constraints to Sustainable Agricultural and Economic Revival, International Journal of Business and Social Research (IJBSR), Vol 3, No 5, pp. 234244.

[8] Gani, I. M.., and Abubakar, A., (2013). Impact of banking sector development on economic Growth: Another look at the evidence from Nigeria. Journal of Business Management \& Social Sciences Research (JBM \& SSR), Vol 2, No 4, pp. 47-57.

[9] Evbuomwan, G .O., Okoye, L .U. and Eke, .O.P. (2018). Effect of Government and Private Sector Financing on the Agricultural sector in Nigeria. A paper presented at the $31^{\text {st }}$ international Business Management Association,
Retrieved from www.researchgate.net . Accessed $20^{\text {th }}$ February 2020.

[10] Ayeomoni, I.O and Aladejana, A.S. (2016). Agricultural Credit and Economic Growth Nexus. Evidence from Nigeria, International Journal of Academic Research in Accounting, Finance and management Sciences, Vol 6, No 2, pp. 146-158

[11] Lefty,.N. (2012). What is "economic Growth, Retrieved from www.thormhartmann.com Accessed $9^{\text {th }}$ December 2019.

[12] Ojiegbe, J.E and Duruechi, A.H (2015). Agricultural Loans, as Catalyst for Food Production in Nigeria: The Problems and Prospects, Journal of Research in World Economy, Vol 6, No 4, pp 53-63.

[13] Chen,.J. (2018). Agricultural Credit, Retrieved from www.investopedia.com Accessed 25 ${ }^{\text {th }}$ November 2019

[14] Chappelow,J .(2019). Gross Domestic Product-GDP. Retrieved from www.investopedia.com. Accessed $14^{\text {th }}$ November,2019

[15] Smith, .A. (1776). Wealth of Nations, $1^{\mathrm{ST}}$ Edition, London: W. Strahan and T. Cadell

[16] Jhingan M.L. (2004), Money, Banking, International Trade and Public Finance,7th Revised Edition, New Delhi: VRINDA publication Ltd.

[17] Lema, A and Paul,.F. (2018). The Dynamic Synergies between Agricultural Financing and Economic Growth of Tanzania, African Journal of Economic Review, Vol 4, No 2,pp. 46- 60.

[18] Ayim, S. A. and Orok, A.B. (2017). The Impact of Agricultural Credit Guarantee Scheme Fund on Agricultural Sector Development in Nigeria. International Review of Management and Business Research, Vol 6, No 3, pp.1104-1116

[19] Ayeomoni, I.O and Aladejana, A.S. (2016). Agricultural Credit and Economic Growth Nexus. Evidence from Nigeria, International Journal of Academic $R$ Research in Accounting, Finance and management Sciences, Vol 6, No 2, pp. 146-158. 
[20] Duke, S. B., Mbat, D. O. and. Udoka, C. O., (2016). The Effect of Commercial Banks' Credit on Agricultural Production in Nigeria, Journal of Finance and Accounting, Vol 4, No 1, pp. 1-10.

[21] Gabriel,E.E., Anthony.O., and Arikpo. OF (2015). The Contribution of Deposit Money Banks on the growth of the Agricultural sector in Nigeria, Advances in Social Sciences Research Journal, Vol 3, No 2, pp. 33-42.

[22] Khan,W., Fatima,S.,and Jamshed, M. (2017) Agricultural Credit-led Agricultural Growth: A VECM

Approach , Asian Journal of Agricultural Extension, Economics \& Sociology, Vol 19, No 1, pp. 1-16.

[23] Ikpefan, .O.A.(2007) Financing Agricultural Cooperative Societies in Nigeria: Challenges and prospects, Journal of cooperatives

\section{Contribution of individual authors to the creation of a scientific article (ghostwriting policy)}

Mosinmileoluwa Afolabi, wrote the paper, conceptualized, methodology.

Godswill Osagie Osuma, wrote the paper, review, methodology

Ochei Ailemen Ikpefan, wrote the paper, review Grace Evbuomwan, wrote the paper, review

\section{Sources of funding for research presented in a scientific article or scientific article itself}

This article was funded by Covenant University Center for Research Innovation and Discovery (CUCRID)
[24] Pearson, M.H., and Shin, Y. (1998). Generalized Impulse Response Analysis in Linear Multivariate Models. Economics Letters, Vol 56, pp. 17-29.

[25] Osuagwu, E.S. (2020). Empirical Evidence of a Long-Run Relationship Between Agriculture and Manufacturing Industry Output in Nigeria, SAGE open journal Vol 10, No 1, pp. 1-12.

[26] Bakulina, G., Fedoskin, V., Pikushina, M., Kukhar, V., and Kot, E.(2020) Factor Analysis Models in Enterprise Costs Management, International Journal of Circuits, Systems and Signal Processing, Vol 14 pp.232-240

[27] Meshref,. H. (2020). Predicting Loan Approval of Bank Direct Marketing Data Using Ensemble Machine Learning Algorithms, International Journal of Biology and Biomedical Engineering, Vol 14, pp. 826-832.

\section{Creative Commons Attribution License 4.0 (Attribution 4.0 International, CC BY 4.0)}

This article is published under the terms of the Creative Commons Attribution License 4.0

https://creativecommons.org/licenses/by/4.0/deed.en_US 